\title{
Cholestenoic acid, an endogenous cholesterol metabolite, is a potent $\gamma$-secretase modulator
}

Joo In Jung 1,2,3, Ashleigh R. Price ${ }^{1,2,3}$, Thomas B. Ladd1 1,2,3, Yong Ran 1,2,3, Hyo-Jin Park ${ }^{1,2,3}$, Carolina Ceballos-Diaz ${ }^{1,2,3}$, Lisa A. Smithson 1,2,3, Günther Hochhaus ${ }^{4}$, Yufei Tang ${ }^{4}$, Rajender Akula ${ }^{5}$, Saritha Ba ${ }^{5}$, Edward H. Koo ${ }^{6,8}$, Gideon Shapiro ${ }^{7^{*}}$, Kevin M. Felsenstein ${ }^{1,2,3^{*}}$ and Todd E. Golde ${ }^{1,2,3^{*}}$

\begin{abstract}
Background: Amyloid- $\beta$ (A $\beta$ ) 42 has been implicated as the initiating molecule in the pathogenesis of Alzheimer's disease (AD); thus, therapeutic strategies that target $A \beta 42$ are of great interest. $\gamma$-Secretase modulators (GSMs) are small molecules that selectively decrease A 342 . We have previously reported that many acidic steroids are GSMs with potencies ranging in the low to mid micromolar concentration with $5 \beta$-cholanic acid being the most potent steroid identified GSM with half maximal effective concentration ( $E_{50}$ ) of $5.7 \mu \mathrm{M}$.

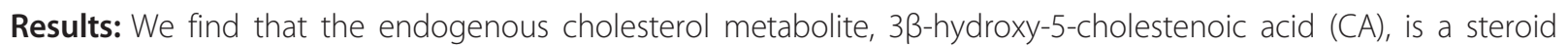
GSM with enhanced potency ( $E C_{50}$ of $250 \mathrm{nM}$ ) relative to $5 \beta$-cholanic acid. $C A$ i) is found in human plasma at 100-300 nM concentrations ii) has the typical acidic GSM signature of decreasing A $\beta 42$ and increasing $A \beta 38$ levels iii) is active in in vitro $\gamma$-secretase assay iv) is made in the brain. To test if CA acts as an endogenous GSM, we used Cyp27a1 knockout (Cyp27a1-/-) and Cyp7b1 knockout (Cyp7b1-/-) mice to investigate if manipulation of cholesterol metabolism pathways relevant to CA formation would affect brain Aß42 levels. Our data show that Cyp27a1-/- had increased brain A 342 , whereas Cyp7b1-/- mice had decreased brain A 42 levels; however, peripheral dosing of up to $100 \mathrm{mg} / \mathrm{kg}$ CA did not affect brain A $\beta$ levels. Structure-activity relationship (SAR) studies with multiple known and novel CA analogs studies failed to reveal CA analogs with increased potency.
\end{abstract}

Conclusion: These data suggest that CA may act as an endogenous GSM within the brain. Although it is conceptually attractive to try and increase the levels of $C A$ in the brain for prevention of $A D$, our data suggest that this will not be easily accomplished.

Keywords: Cholestenoic acid, $\gamma$-secretase modulator (GSM), Amyloid, Alzheimer disease, Cholesterol, Steroid, Bile acid, Cytochrome P450

\section{Background}

Accumulation of aggregated amyloid $\beta$ peptides $(A \beta)$ in the brain is proposed to be a key trigger in a complex neuropathological cascade that leads to Alzheimer's disease (AD). $A \beta$ is produced from the amyloid precursor protein (APP) through sequential proteolytic cleavages [1]. APP is first cleaved by $\beta$-secretase to produce a

\footnotetext{
*Correspondence: gideon.shapiro@gmail.com; kfelsenstein0@ufl.edu; tgolde@ufl.edu

7Pharmore, Inc., Gainesville, FL 32653, USA

'Center for Translational Research in Neurodegenerative Disease, University of Florida, Gainesville, FL 32610, USA

Full list of author information is available at the end of the article
}

soluble APP $\beta$ and a membrane anchored APP carboxyl terminal fragment (CTF $\beta)$. The CTF $\beta$ is then cleaved by $\gamma$-secretase to produce extracellular $A \beta$ peptides and APP-intracellular domain (AICD) fragments. Notably, a number of $A \beta$ peptides are normally produced, with A $\beta 40$ being the most abundant species with minor species including, but not limited to, $\mathrm{A} \beta 37,38,39$ and 42 routinely observed in most studies. These various species are not produced by simple classic endoproteolysis at multiple sites, but appear to arise from both variation in the initial substrate cleavage site which produces longer $A \beta$ s (i.e., $A \beta 48, A \beta 49$, and $A \beta 51$ ) and the cognate 
AICD, which is then followed by multiple cycles of stepwise, carboxyl-peptidase like cleavages, all of which are mediated by $\gamma$-secretase. Although all $A \beta$ peptides normally produced appear to accumulate in the human $\mathrm{AD}$ brain, the minor $\mathrm{A} \beta 42$ species is typically the most prevalent form that accumulates in the brain parenchyma $[2,3]$. Additional lines of evidence further support the concept $A \beta 42$ is the most pathogenic isoform [4], whereas $A \beta 40$ may, under some circumstances, be a protective isoform [5, 6]. Many early onset familial AD (FAD) mutations linked with APP and Presenilin (PSEN, the catalytic subunit of $\gamma$-secretase) increase the relative levels of $\mathrm{A} \beta 42$ [7-10]. In vitro studies show that $A \beta 1-42$ has a much stronger tendency to aggregate than $A \beta 1-40$ [11]. In $A D$ mouse model, $A \beta 42$ plays a role as a seeding molecule for amyloid deposition but $A \beta 40$ [6] does not. In fact, $A \beta 40$ appears to prevent mice from amyloid deposition $[5,12]$. Moreover, $A \beta x-42$ is the earliest detectable $A \beta$ isoform in the brain parenchyma [13-16]. The role of other shorter carboxylterminal truncated species is at this point unclear, though it is hypothesized that they may behave like A $\beta 40$ [5, 17]. Altogether, there is ample rationale that decreasing the levels of $A \beta 42$ could be a prophylactic approach to prevent accumulation of $\mathrm{A} \beta$ and, thereby, delay or prevent the development of AD.

There have been studies demonstrating that production and processing of $A \beta$ can be influenced by membrane lipid composition [18-21]. In particular, membrane cholesterol appears to play an important role [18]. APP-CTF $\beta$ and $\gamma$-secretase are found in lipid rafts, composed primarily of cholesterol [18]. Further, it has been shown that cholesterol directly binds to the APP-CTF $\beta$ substrate $[22,23]$. The interdependent interactions among the three components (APP-CTF $\beta, \gamma$-secretase, and cholesterol) are postulated to create the optimal microenvironment for $A \beta$ production. Indeed, it has been reported that $\gamma$-secretase activity is largely dependent on the amount of cholesterol, which affects $A \beta$ production as a result $[18,24]$ though others have not reproduced this finding [25]. These observations suggest the potential for modulating $\gamma$-secretase activity and thus altering the overall $A \beta$ levels or the ratios of $A \beta$ isoforms produced by steroid derivatives as cholesterol surrogates.

Previously, we have reported steroid carboxylic acid $\gamma$ secretase modulators (GSMs) [26]. Numerous acidic steroids decrease $A \beta 42$ levels and increase $A \beta 38$ levels without changing total $A \beta$ or $A \beta 40$ levels [26]. Acidic steroid GSMs have gross structural similarity to the established-NSAID based GSMs in that a carboxylic acid group, that is key for GSM activity, is attached by a carbon tether chain to a highly lipophilic core structure [26, 27]. 5 $\beta$-Cholanic acid (ursocholanic acid) was the most potent steroid GSM identified in our previous study with an $\mathrm{EC}_{50}$ of $5.7 \mu \mathrm{M}$, but the endogenous bile acids, lithocholic acid and ursocholic acid, were also found to be GSMs [26]. Mechanistically, GSMs decrease production of $A \beta 42$ selectively by promoting step-wise $\gamma$-secretase cleavage and, thus, inherently increase shorter $A \beta$ peptides $[28,29]$. Because $\gamma$-secretase cleavage activity participates in a broad spectrum of cellular signaling mechanisms (i.e., Notch-1) [30], indiscriminate inhibition of $\gamma$-secretase activity has been essentially abandoned as a therapeutic approach for $\mathrm{AD}$ due to debilitating side effects associated with target-based toxicity. In contrast, GSMs do not alter overall $\gamma$-secretase activity, appear to be relatively selective for APP, and are, therefore, thought to be an intrinsically safe mechanistic approach to $\mathrm{AD}$ therapy; however, it has been challenging to identify GSMs that are potent, have sufficient brain penetrance, and lack off-target toxicity.

Considering that GSMs derived from synthetic compounds have toxicity issues that are not associated with target-based toxicity, we have explored whether other naturally occurring acidic steroids might have sufficient potency to be therapeutically useful. An extended screening identified $3 \beta$-hydroxy-5-cholestenoic acid (CA) as a highly potent $\mathrm{GSM}$ with an $\mathrm{EC}_{50}$ for $\mathrm{A} \beta 42$ lowering of $250 \mathrm{nM}$. As CA is produced endogenously during the course of cholesterol elimination in many extrahepatic organs including the brain [31,32] and is present in human plasma at concentrations near its $E_{50}$ for GSM activity, we explored whether CA might function endogenously as a GSM. Our results showed that Cyp27a1-/- [33, 34] and Cyp7b1-/- [35] mice that reduce or increase brain $C A$, respectively, resulted in the predicted brain $A \beta 42$ changes consistent with the hypothesis that CA is an endogenous GSM. Peripheral dosing of $\mathrm{CA}$ in wild type mice dramatically increased plasma $C A$ levels, but not brain $A \beta$ levels, suggesting limited brain exposure of peripheral CA. Structure-activity relationship (SAR) with multiple known and novel CA analogs studies failed to reveal CA analogs with increased potency. These studies show that though CA is a potent GSM that may act within the brain to regulate $A \beta 42$ levels, exogenous administration of $\mathrm{CA}$ is not likely to be therapeutically useful for lowering $A \beta 42$.

\section{Results}

\section{CA is a potent GSM}

Based on previous studies that showed a number of acidic steroids are GSMs [26], we continued to test other additional acidic steroids for GSM activity. These studies revealed that the endogenous cholesterol metabolite CA (Fig. 1a) had potent GSM activity. In cellbased assays, the $\mathrm{EC}_{50}$ value for decreasing $\mathrm{A} \beta 42$ levels was $250 \mathrm{nM}$ and, consistent with other acidic steroid GSMs, $A \beta 38$ increased without alterations in total $A \beta$ 


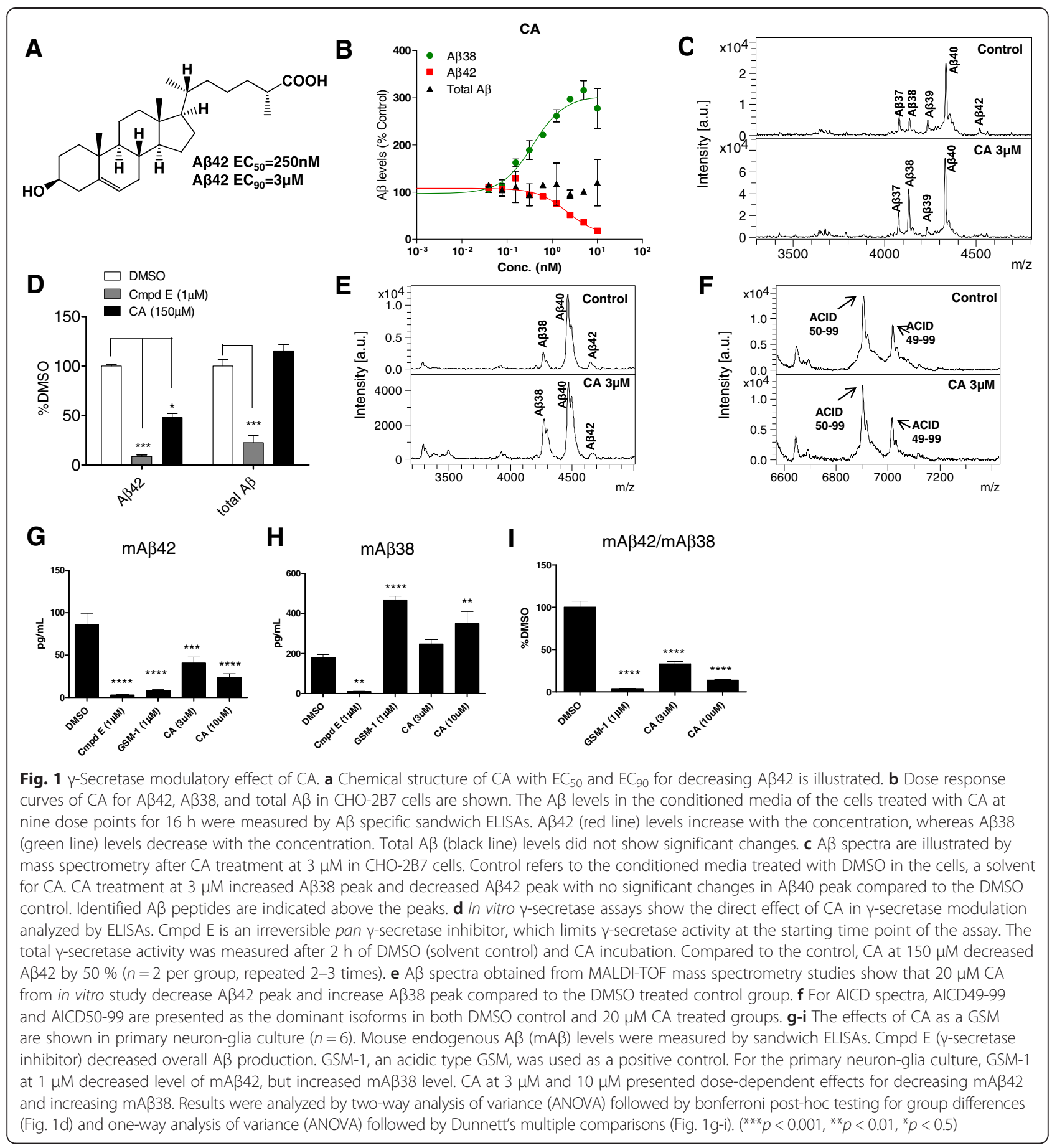

(Fig. 1b). CA's GSM activity was further confirmed by IP/MS analysis using the conditioned media produced from $\mathrm{CHO} 2 \mathrm{~B} 7$ cells, which revealed selective lowering of $A \beta 42$ and increased $A \beta 38$ (Fig. 1c). To assess whether CA has a direct effect on $\gamma$-secretase, we performed in vitro $\gamma$-secretase cleavage assays (Fig. 1d-f). In these assays CA treatment decreased $A \beta 42$ production by $51 \%$ without any significant changes in total $A \beta$ levels when the $A \beta$ levels were compared to DMSO control (Fig. 1d).
Compound E (Cmpd E), a non-selective $\gamma$-secretase inhibitor, decreased both $\mathrm{A} \beta 42$ (91 \%) and total $\mathrm{A} \beta$ (77\%) production significantly (Fig. 1d). These A $\beta$ levels demonstrate the initial $A \beta$ levels in the assays. IP/MS $A \beta$ and AICD profiles from the in vitro assay are illustrated in Fig. 1e and f, respectively. Again CA decreased A $\beta 42$ and increased A 338 (Fig. 1e) and, as noted with previous studies of GSMs, did not affect $\varepsilon$-site utilizations (AICD49-99 and AICD50-99) (Fig. 1f). Next, we utilized primary 
mouse postnatal day $0(\mathrm{P} 0)$ neuron-glia cultures of wildtype mice to determine the effect of $\mathrm{CA}$ on endogenous mouse $A \beta(m A \beta)$ levels (Fig. 1g-j). CA decreased $\mathrm{mA} \beta 42$ production by $\sim 60 \%$ at $3 \mu \mathrm{M}$ and by $\sim 75 \%$ at $10 \mu \mathrm{M}$ (Fig. $1 \mathrm{~g}$ ) and increased $\mathrm{A} \beta 38$ production at $10 \mu \mathrm{M}$ (Fig. 1h) resulting in a significant decrease in the $A \beta 42: A \beta 38$ ratio at both concentrations (Fig. 1l). Thus, confirming that CA acts as GSM on primary brain cells.

\section{Loss of Cyp27a1 and Cyp7b1 alters mouse brain $A \beta 42$}

To determine whether $C A$ levels could affect $A \beta 42$ production in vivo, we assessed $\mathrm{A} \beta$ levels in both Cyp27a1+/+, Cyp27a1+/- and Cyp27a1-/- mice brains and Cyp7b1+/+, Cyp7b1+/- and Cyp7b1-/- mice brains. In the brain, Cyp27a1 catalyzes the synthesis of CA from 27-OHC and Cyp7b1 catabolizes CA (Fig. 2a). From the previous literature, loss of Cyp27a1 has been shown to eliminate the levels of 27-OHC production in the mouse brain, suggesting decreased CA levels, whereas loss of Cyp7b1 increases mouse brain CA levels from $\sim 30 \mathrm{nM}$ to $\sim 300 \mathrm{nM}$ [36]. In humans with loss of function mutations in CYP27A1 and CYP7B1, there is reduced and elevated CSF or plasma CA, respectively [36]. For our studies, mouse brains were harvested at 3 months and endogenous mouse $A \beta$ levels measured by ELISA. Fig. $2 b$ shows $m A \beta 42 / m A \beta 40$ ratio measured from the Cyp27a1 mouse brains. There was a significant $23 \%$ increase in the $\mathrm{mA} \beta 42 / \mathrm{mA} 440$ ratio in Cyp27a1-/- mice compared to Cyp27a1+/+ (Fig. 2b). Because Cyp27a1 mice were poor breeders, we did not obtain enough animals for an accurate measurement of brain A $\beta 38$ levels. Conversely, Cyp7b1-/- mice showed a significant $21 \%$ decrease in $\mathrm{mA} \beta 42 / \mathrm{mA} \beta 40$ ratio (Fig. 2c) and a significant $25 \%$ increase in $\mathrm{mA} \beta 38 / \mathrm{mA} \beta 40$ ratio (Fig. $2 \mathrm{~d}$ ) compared to control Cyp7b1+/+ mice. In all cases, the ratios of $\mathrm{mA} \beta 40 / \mathrm{mA} \beta 42$ and $\mathrm{mA} \beta 38 / \mathrm{mA} \beta 40$ in heterozygous Cyp27a1 or Cyp7b1 mice (Cyp27a1+/- or Cyp7b1+/-) were intermediate between wild type and null animals, although the differences were not statistically significant. We attempted to observe amyloid plaque pathology in the context of Cyp7b1 or Cyp27a1 deficiency. Extensive efforts were made to breed $\mathrm{APP}_{(\mathrm{KM} 670 / 671 \mathrm{NL}+\mathrm{V717F})}$ CRND8
A

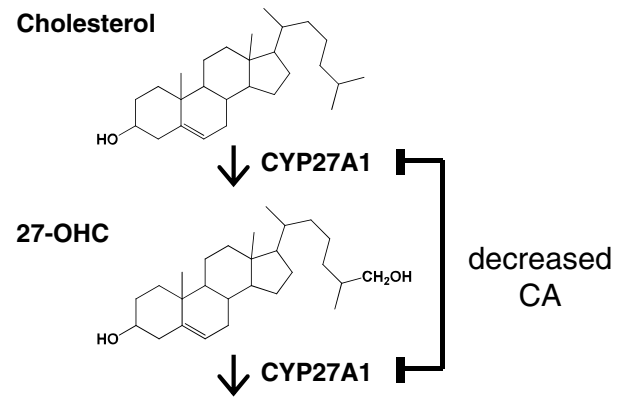

CA

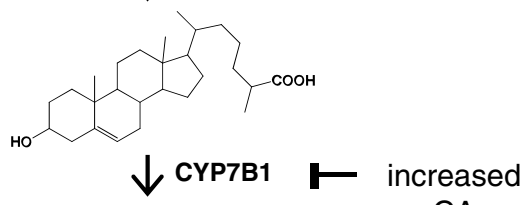

7a-OH-CA

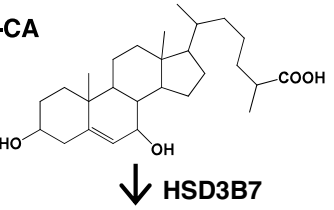

7a-OH-4-CA

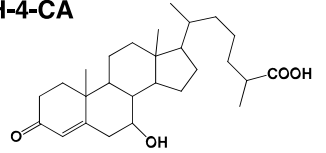

B

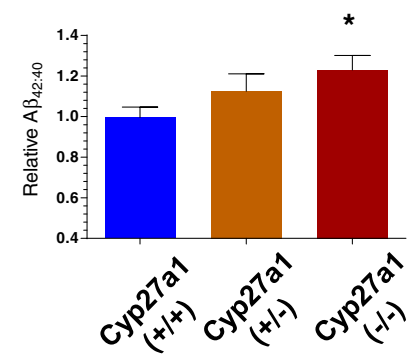

C

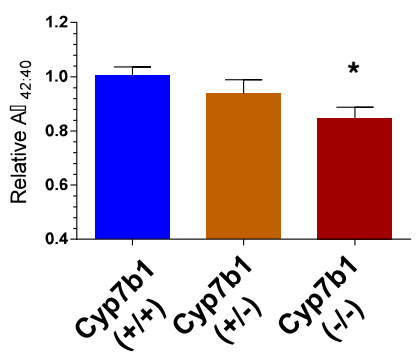

D

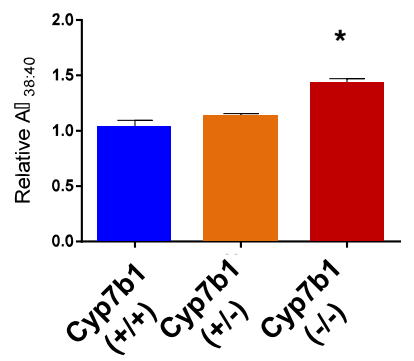

Fig. 2 The effects of Cyp27a1 and Cyp7b1 genetic reductions on brain mAß levels. a CA is found in the acidic cholesterol elimination pathway. Cholesterol is hydrolyzed by Cyp27a1 to produce 27-hydroxycholesterol (27-OHC) and CA sequentially. CA is further metabolized by Cyp7b1 generating CA derivatives, 7a-hydroxy-cholestenoic acid (7a-OH-CA) and 7a-hydroxy-4-oxo-cholestenoic acid (7a-OH-4-CA). Genetic deletion of Cyp27a1 is predicted to decrease endogenous CA levels, whereas the deletion of Cyp7b1 is predicted to accumulate CA. b Cyp27a1 (-/-) increased brain mAß42/Aß40 ratio compared to Cyp27a1 (+/+) by $20 \%$. c-d Cyp7b1 (-/-) decreased the ratio between mAß42 to mAß40 by $20 \%$

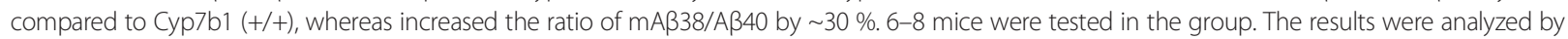
one-way analysis of variance (ANOVA) followed by Dunnett's multiple comparisons. ${ }^{*} p<0.05$ 
transgenic mice onto or Cyp7b1-/- genotype, but these efforts were unsuccessful. Though a few APP+/on the Cyp7b1-/- backgrounds were generated, none of these survived past 3 months of age. Thus, we were unable to evaluate the effects of loss of Cyp7b1 on amyloid deposition.

\section{Intraperitoneal injections of CA did not alter mouse brain} $A \beta$ levels

To test the acute effect of CA in vivo, CA (30 mg/kg) or GSM-1 (30 mg/kg), a potent GSM compound (Fig. 3), was given to wild type mice, and the brains were harvested after $30 \mathrm{~min}, 1,2$, and $3 \mathrm{~h}$. While the positive control GSM-1 showed the expected A $\beta$ modulation in mouse brains after three hours post intraperitoneal (IP) injection [37], there were no changes in $A \beta$ levels after $\mathrm{CA}$ administration (Fig. 3a-c). It should be noted in these studies that the half-life $\left(T_{1 / 2}\right)$ for CA in humans is reported to be $90 \mathrm{~min}$ [38]. Next, a dose-response study was performed with CA given to wild type mice at $30,60,75$, and $100 \mathrm{mg} / \mathrm{kg}$ doses with brains harvested $3 \mathrm{~h}$ after dosing. CA was well tolerated in mice up to the highest concentration (100 mg/kg). The Fig. 3d demonstrates CA plasma concentrations after injections of various doses in $\mathrm{C} 57 \mathrm{BL} / 6$ mice. The standard curve for CA measurement showed a linear response with the limit of quantification of $100 \mathrm{ng} / \mathrm{mL}(\sim 250 \mathrm{nM})$, which is close to physiological plasma CA concentration (100$300 \mathrm{nM})[39,36,40]$. When different doses $(30,60,75$, $100 \mathrm{mg} / \mathrm{kg}$ ) of CA were injected, plasma CA concentrations increased in dose dependent manner from $200 \mathrm{ng} / \mathrm{mL}(\sim 500 \mathrm{nM})$ at $30 \mathrm{mg} / \mathrm{kg}$ dose to $4000 \mathrm{ng} / \mathrm{mL}$ $(\sim 10 \mu \mathrm{M})$ at $100 \mathrm{~kg} / \mathrm{mg}$ dose (Fig. 3d). This might indicate some non-linearity in pharmacokinetics of CA. No significant effects of $\mathrm{CA}$ on $\mathrm{mA} \beta 42, \mathrm{~mA} \beta 38$, and total $\mathrm{mA} \beta$ compared to the vehicle-injected control were

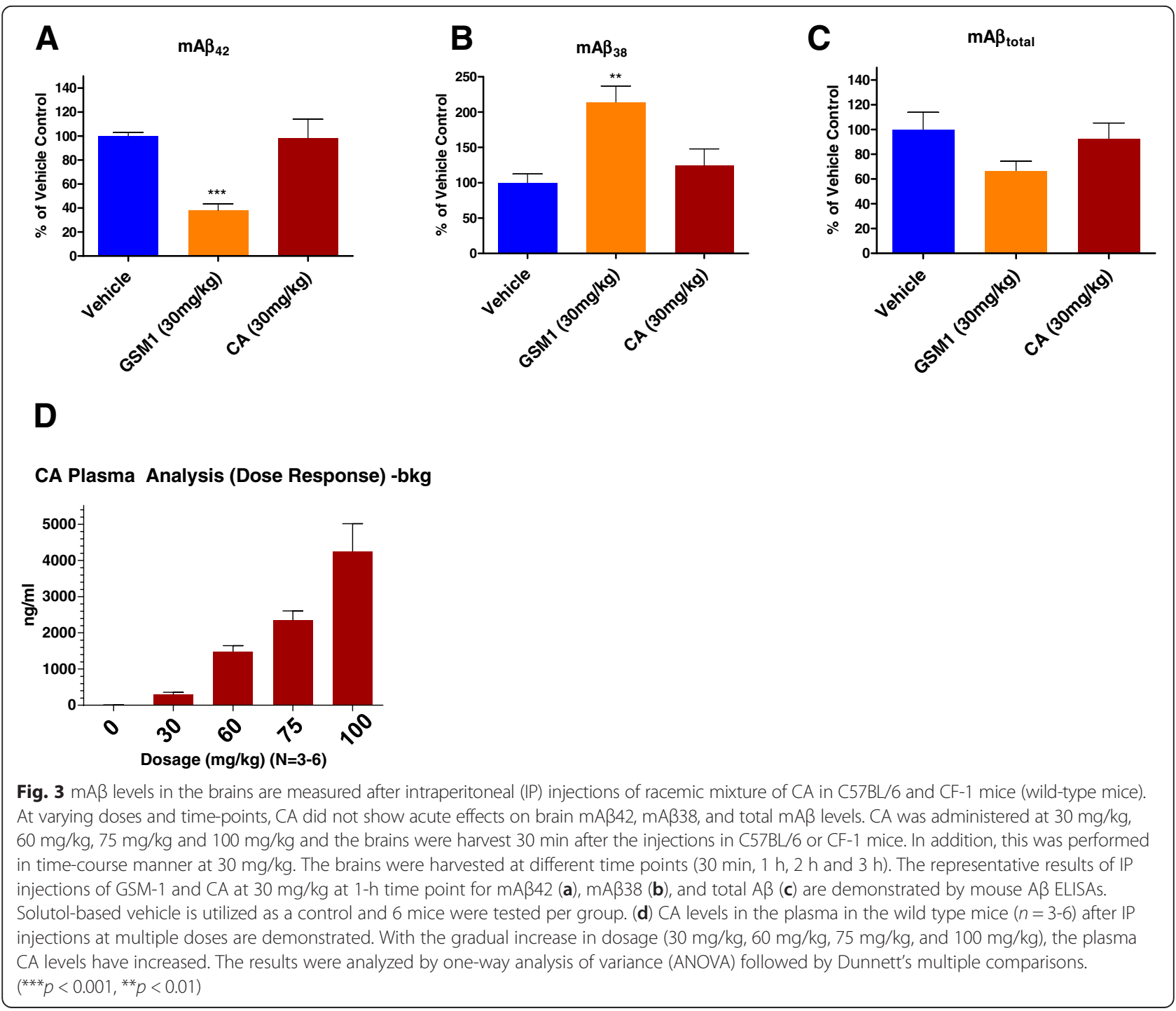


observed up to the highest $100 \mathrm{mg} / \mathrm{kg}$ dose (data not shown).

\section{GSM activity of CA analogs}

We had previously screened 170 commercially available steroids and identified $5 \beta$-cholanic acid as the most potent steroid GSM within that set of compounds [26]. $5 \beta$-Cholanic acid 1 (Fig. 4) decreased $\mathrm{A} \beta 42$ with an $\mathrm{EC}_{50}$ of $5.7 \mu \mathrm{M}$ [26]. In this report, we have identified CA $\mathbf{2 a}$ as a potent GSM with an $\mathrm{EC}_{50}$ of $250 \mathrm{nM}$ for decreasing A $\beta 42$. As such, $\mathbf{2 a}$ was comparable in potency to an optimized GSM clinical candidate phenylacetic acid EVP09623 and to preclinical tool compound GSM-1 4, as representative reference compounds from the carboxylic acid chemotype (Fig. 4).

A striking structural feature of CA relative to previous potent GSMs is the extended C5 alkylene tether linking the carboxylate group to the lipophilic core steroid nucleus. To date, potent GSMs such as 3 and 4 have been acetic acids in which the carboxylate group is linked to a core lipophilic moiety by a single carbon atom. To evaluate the effects of the alkylene tether, the structural-activity relationship (SAR) for CA analogs varying the tether from 3 methylenes to 7 methylenes (C3-C7) was examined (Table 1). The synthetic chemistry processes for both 25-(R) and 25-(S) pure diastereomers of CA, as well as the other CA analogs in Table 1, are illustrated and detailed in Additional file 1. Shorter tether analogs 5 (C3 tether analog) and 6 (C4 tether analog) displayed an order of magnitude lowering of potency with $\mathrm{EC}_{50}$ values of $\sim 2.0 \mu \mathrm{M}$. The extended $\mathrm{C} 6$ and $\mathrm{C} 7$ tether analogs $\mathbf{1 0}$ and $\mathbf{1 1}$ exhibited a slight decline in potency $\left(\mathrm{EC}_{50}=391 \mathrm{nM}\right.$ and $513 \mathrm{nM}$ respectively) relative to the baseline $\mathrm{C} 5$ analog 7 .

The SAR around the optimal C5 tether structure was elucidated with the analogs $2 \mathbf{a}, 2 \mathbf{b}, 7, \mathbf{8}$ and $\mathbf{9}$. The 25-(S)-CA, the methyl group diastereomer $\mathbf{2 b}$, was about 2-fold less potent than the 25-(R)-CA 2a. The simple unsubstituted $\mathrm{C} 5$ methylene tether analog 7 displaying an $\mathrm{EC}_{50}$ of $\sim 110 \mathrm{nM}$ was more potent than 2a. The corresponding $\alpha, \beta$-unstaturated analog $\mathbf{8}$ was virtually equipotent to 7 . This steroid SAR at the $\alpha$-carbon to the carboxylic acid group differs markedly from the SAR of PAA GSMs such as compound 3 (Fig. 4) where methyl substitution increases potency. Difluoro analog 9 prepared to favor the putative active ionized carboxylate, in fact, exhibited an order of magnitude loss in potency relative to the other $\mathrm{C} 5$ analogs.

We further explored the SAR of endogenous CA catabolites found in the acidic pathway (Fig. 5a). 27-OHC, the precursor of CA, is inactive as a GSM since it is missing the critical carboxylate group. $\mathrm{CA}$ is then converted to $7 \alpha-\mathrm{OH}-\mathrm{CA}$ and then to $7 \alpha-\mathrm{OH}-3-\mathrm{CA}$, therefore we tested them for GSM activity in dose dependent

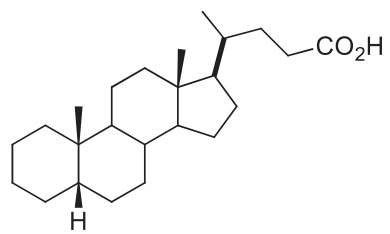

$15 \beta$-cholanic acid $\mathrm{A} \beta 42 \mathrm{EC}_{50}=5700 \mathrm{nM}$<smiles>O=C(O)C(CC1CCC1)c1cc(Cl)c(OCC(F)(F)F)c(-c2ccc(C(F)(F)F)cc2)c1</smiles>

3 EVP-0015962

$\mathrm{A} \beta 42 \mathrm{EC}_{50}=67 \mathrm{nM}$<smiles>CC(CCC[C@H](C)C(=O)O)C1CCC2C3CC=C4C[C@@H](O)CC[C@]4(C)C3CC[C@]12C</smiles>

2a 25(R)-cholestenoic acid $\mathrm{A} \beta 42 \mathrm{EC}_{50}=250 \mathrm{nM}$<smiles>CC(C)CC(Br)N1CC[C@@H](CC(=O)O)C[C@H]1c1ccc(C(F)(F)F)cc1</smiles>

4 GSM-1 Ar=4-CIPh $\mathrm{A} \beta 42 \mathrm{EC}_{50}=92 \mathrm{nM}$

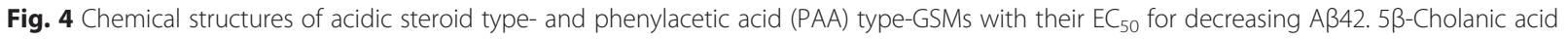
(1) has a four-ring structure with a 4-carbon side chain on carbon 17 and its $E_{50}$ for decreasing A 442 is $\sim 5.7 \mu M$. 25(R)-cholesteonic acid (2a) has the same four-ring structure with an additional hydroxyl group on carbon 3 and a 6-carbon side chain on carbon 17 . For this molecule, the $\mathrm{EC}_{50}$ is at 250 nM. EVP-0015962 (3), (R)-2-(5-chloro-6-(2,2,2-trifluoroethoxy)-4'-(trifluoromethyl)biphenyl-3-yl)-3-cyclobutylpropanoic acid, shows GSM activity at $\mathrm{EC}_{50}$ of $67 \mathrm{nM}$ from the previous literature. GSM-1 (4) has the two phenyl rings with the carboxylic acid functional group. The $\mathrm{EC}_{50}$ for GSM-1 is at $92 \mathrm{nM}$ 
Table $1 C A$ analogs $E_{50}$ for lowering $A \beta 42$

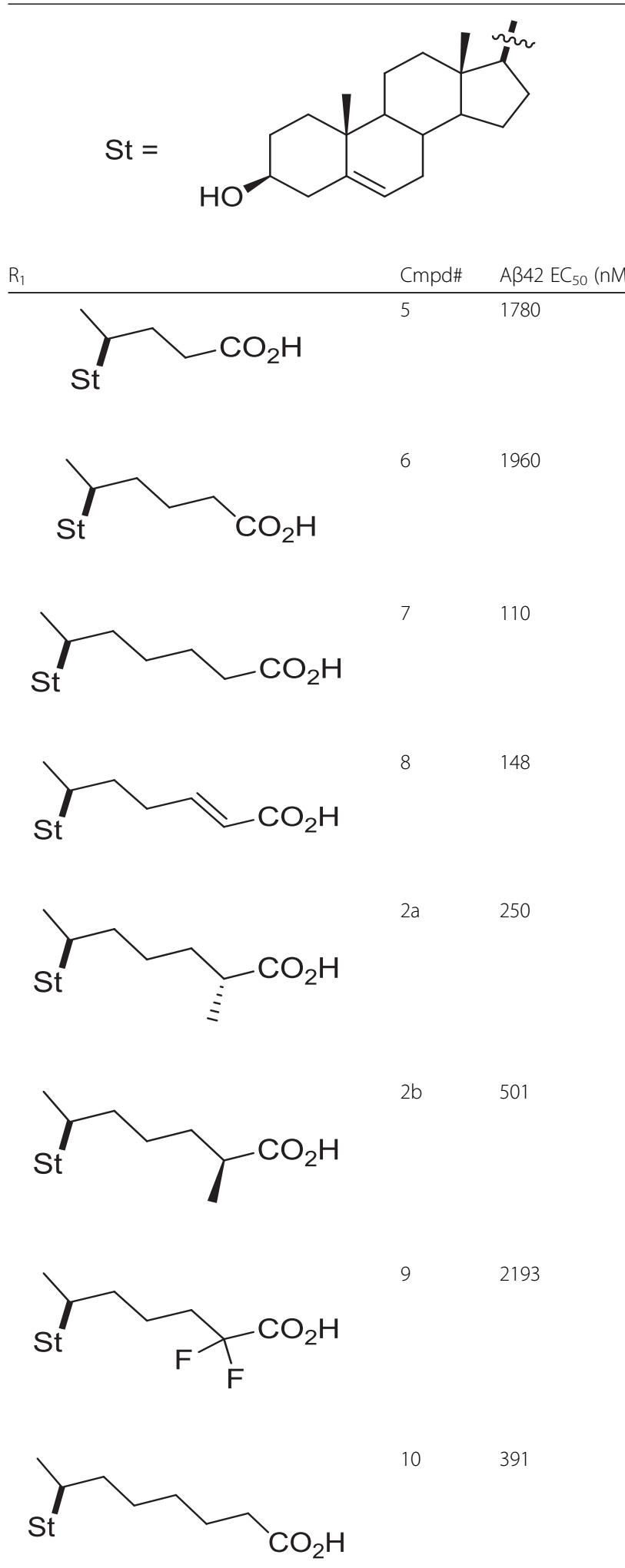

Table 1 CA analogs $\mathrm{EC}_{50}$ for lowering A $\mathrm{A} 42$ (Continued)

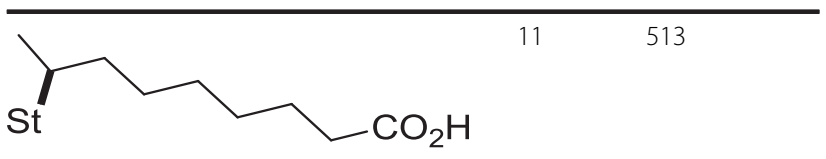

$\mathrm{EC}_{50}=$ half maximal effective concentration

studies (Fig. 5a). Both $7 \alpha-\mathrm{OH}-\mathrm{CA}$ and $7 \alpha-\mathrm{OH}-3-\mathrm{CA}$ demonstrated GSM activity but were not as potent as CA (Fig. 5a and b). Additionally, we aimed to substitute fluorine (F) at the carbon 3 and 7 positions of the CA catabolites as such fluorine substations can block metabolism (12-13 in Table 2). Replacement of a 3-OH group of $\mathrm{CA}$ with a $3 \beta-\mathrm{F}$ group could be readily achieved to give 12 using standard methods. Somewhat surprisingly this modification in $\mathbf{1 2}$ resulted in great reduction in GSM potency. Attempts to synthesize the 7-F analog of CA were unsuccessful by routes based on standard diethylaminosulfur trifluoride (DAST) reaction of a corresponding 7-OH intermediate. 7-F delta-5-ene allyl fluoride steroid compounds could be isolated by DAST reaction, however these compounds demonstrated instability in our and previous studies [41, 42]. We also synthesized 3-deoxy-CA 13 based on our previous GSM SAR findings with cholenic acid analogs [26] and this demonstrated an EC50 of 670nM, approximately 3-fold less potent than CA. Collectively, these data demonstrate that endogenous $\mathbf{2 b}$ CA is a relatively optimized steroidGSM.

\section{Carboxylic acid tether combined to PAA chemotypes did not show GSM activities}

As phenyl acetic acid (PAA) chemotype GSMs have low nanomolar potencies for decreasing A $\beta 42$ (Fig. 4, compound 3), we examined whether increasing the length of the carboxylate tether to the PAA moiety could provide a path to further potency increases. The structures of the compounds synthesized are illustrated in Fig. 6a (the synthesis schemes are provided in Additional file 1). Biphenyl moieties (Fig. 6) were selected because they showed optimized drug potencies for GSM effects in previous studies [37, 43, 44]; however, no studies have been investigated regarding the PAA chemotype GSMs combined with the extended alkylene tether. Therefore, we decided to examine whether or not this feature can enhance potencies. We tested for potential GSM activity of these compounds by measuring A $\beta 42$ levels at 300nM and $3 \mu \mathrm{M}$ (Fig. 6b-c); however, these analogs did not demonstrate GSM activities at either concentration. Altogether, these data indicate that the increased potency observed with the C5 carboxylate tether appears to be specific to the steroid based GSMs and does not extend to other acid GSM chemotypes. 


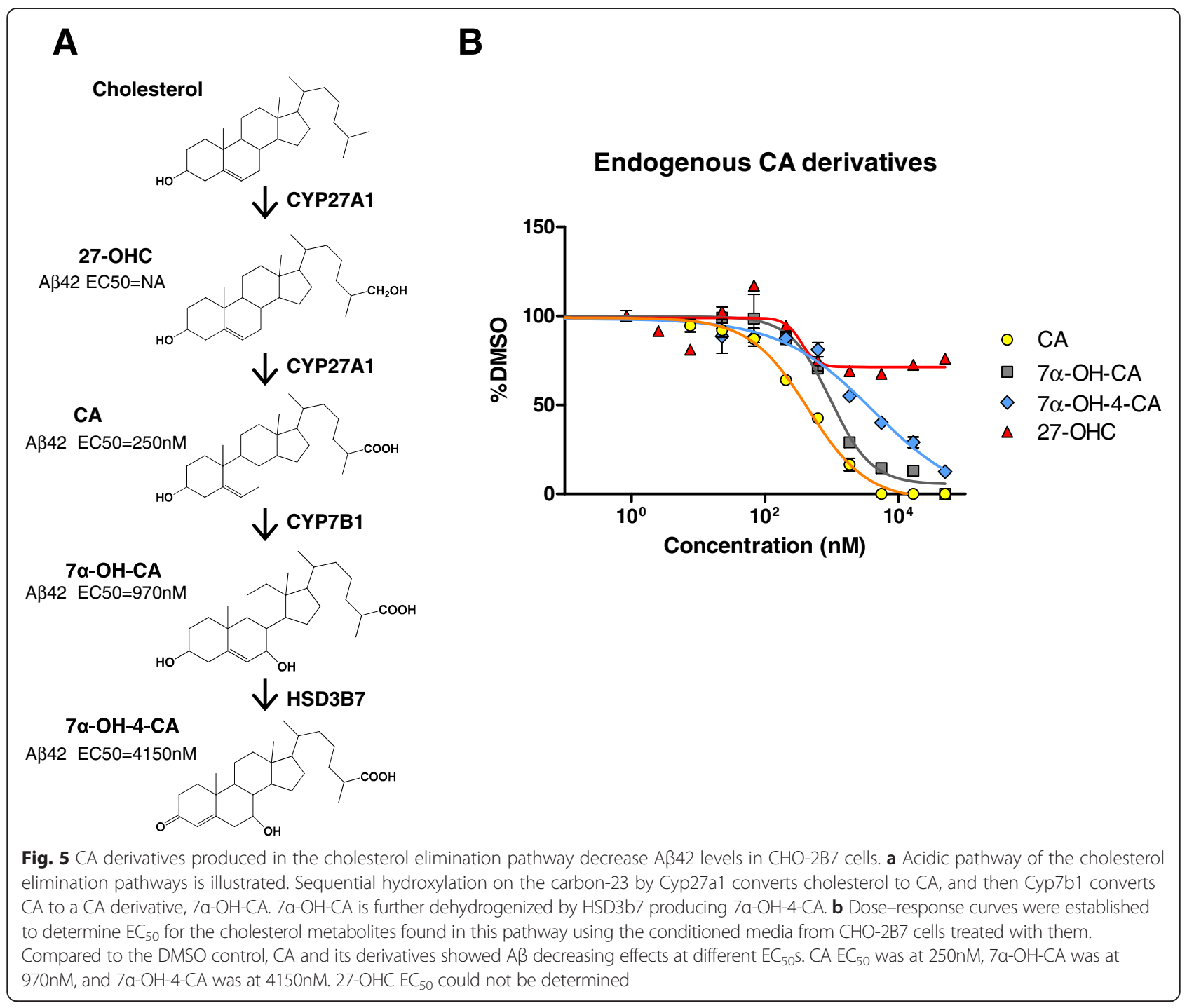

Table 2 Fluorine and deoxy $C A$ analogs $E_{50}$ for lowering $A \beta 42$

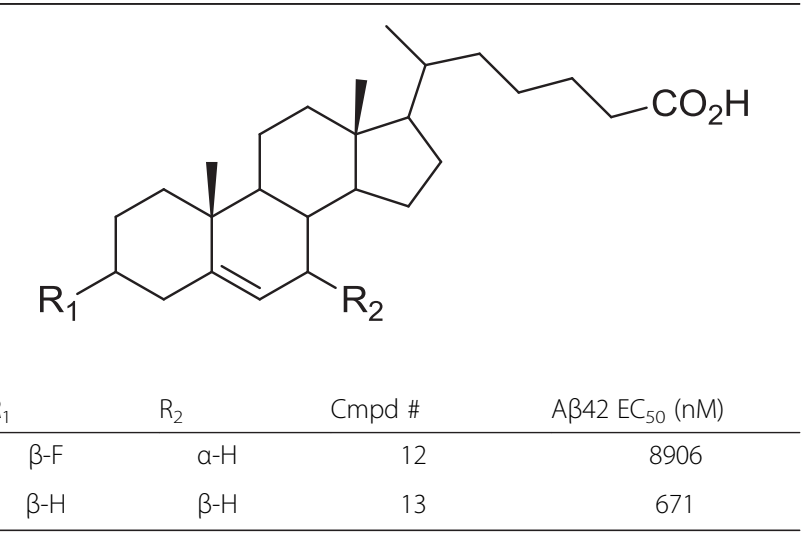

$\mathrm{EC}_{50}=$ half maximal effective concentration

\section{Discussion}

In this study, we identified CA as a potent acidic GSM with an $\mathrm{EC}_{50}$ for lowering $\mathrm{A} \beta 42$ of $\sim 250 \mathrm{nM}$, a concentration well within the normal range of CA levels in human plasma $(\sim 100-300 \mathrm{nM})$. This data raised the possibility that CA was an endogenous GSM and that increasing brain CA levels might be a safe approach to lower brain A 442 levels. Peripheral dosing of CA, however, did not lower brain $A \beta 42$ despite extremely high $C A$ levels in the plasma $(\sim 10 \mu \mathrm{M})$, indicating that either $\mathrm{CA}$ does appear to readily cross the blood brain barrier or, if it does, is rapidly exported from the brain. Unfortunately, using our methodology, we were not able to accurately measure CA levels with sufficient sensitivity to accurately measure CA levels in the brains of these mice.

Given the potency of CA as a GSM, we explored whether mice with genetic deletions of Cyp27a1 [33, 34] and Cyp7b1 [35], the two enzymes regulating CA levels 


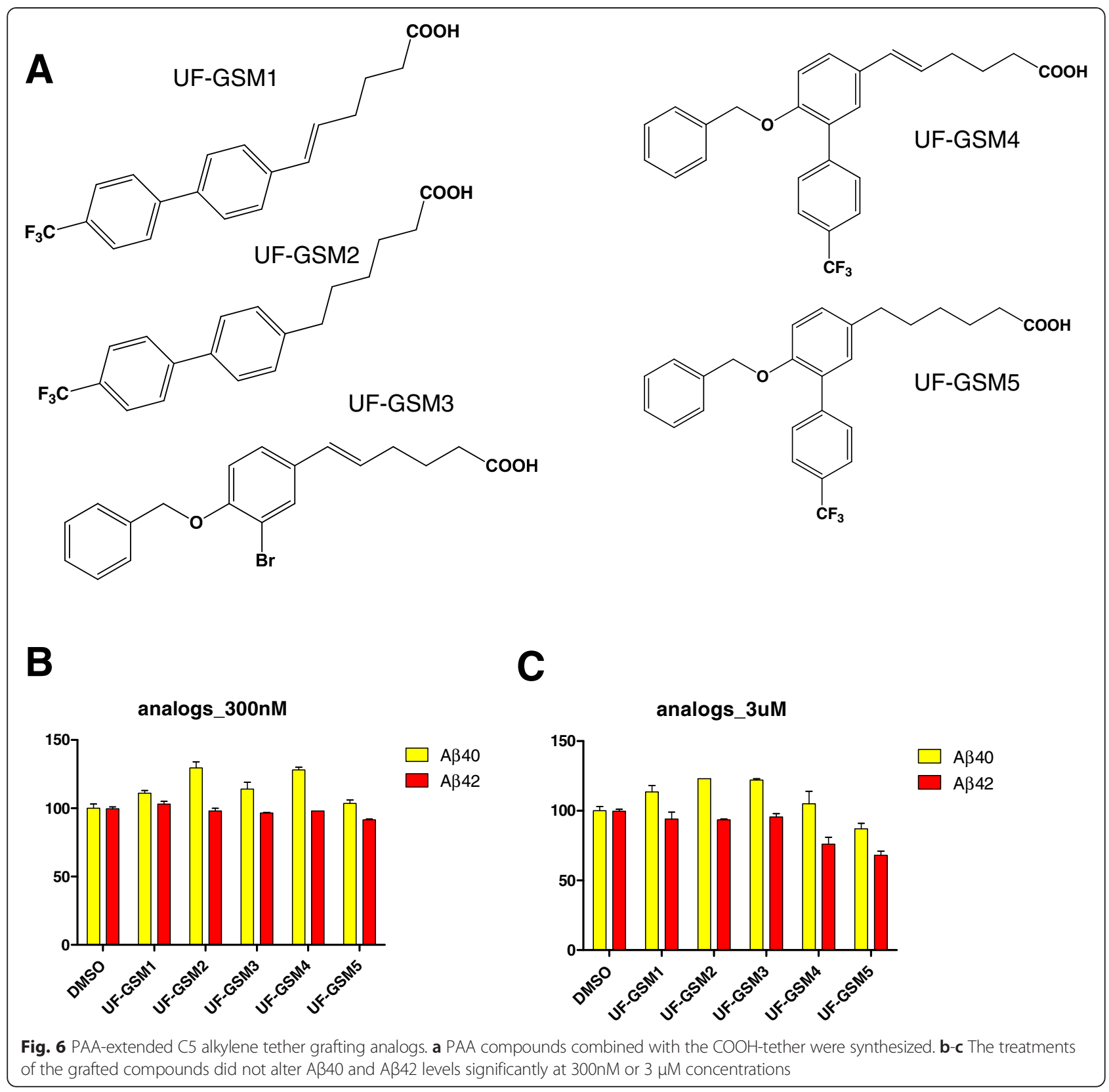

in the brain [31], showed alterations in $\mathrm{mA} \beta 42$ levels. We found that the $\mathrm{mA} \beta 42 / \mathrm{mA} \beta 40$ ratio was increased in the Cyp27a1-/- mice and $\mathrm{mA} \beta 42 / \mathrm{mA} \beta 40$ ratio was decreased in Cyp7b1-/- mice, where CA levels were shown to decrease or increase CA levels, respectively [36]. Given that these shifts in ratio in these knockout mice are precisely what would be predicted if CA demonstrated GSM activity, we concluded that CA is likely to be a bona fide endogenous GSM synthesized in a cholesterol elimination pathway in brain [31]. Given the challenges of measuring levels of endogenous $A \beta$ outside of the brain in wild type mice, we attempted to generate Cyp7b1-/-, APP+/- (CRND8) mice. Despite extensive efforts, we were unable to generate mice with this genotype that lived past 3 months. We did not attempt to cross the CRND8 mice with Cyp27a1-/- mice, because Cyp27a1-/- mice were even less fecund than the Cyp7b1-/- mice. Future studies in humans with genetic loss of function of CYP27A1 that causes cerebrotendinous xanthomatosis (CTX) $[45,36]$ or with genetic loss of function of CYP7B1 deficiency that causes liver failure in children or spastic paraplegia 5 (SPG5) in adults [46, 39, 36], might help to further establish the likelihood that CA is an endogenous GSM, as these patients show altered CA levels and would be predicted to have altered $A \beta 42 / A \beta 40$ ratios $[39,36]$; however, due to the small 
number of patients with these rare disorders, and the severe disease induced by loss of these CYP enzymes, such studies may be challenging to sufficiently power and control.

Building off our previous studies to examine a large number of steroids for GSM and inverse GSM (iGSM) activity [26], we synthesized a number of analogs to see if we can further increase potency. From these studies, we can conclude that $\mathrm{CA}$ seems to represent a relatively optimized steroid GSM, especially the C5 alkene tether linking the carboxylate group to the steroid backbone which appears to be optimal in length for maximizing steroid GSM potency. Indeed, there was a significant increase in GSM potency upon increasing the tether length from $\mathrm{C} 3$ to $\mathrm{C} 5$, but there was only a moderate loss of potency for increased C6 and C7 tether. Based on the observations from extended CA tether analogs, we explored the effects of $\mathrm{C} 5$ alkene tether carboxylates on other acidic GSM "scaffolds". In all cases examined, this "grafting" approach decreased potency, indicating that the positon of the carboxylate group for optimal GSM potency is dependent on the overall structure of the molecule. Further modifications along the steroid backbone all decreased GSM activity relative to CA. For example, both endogenous CA metabolites $7 \alpha-\mathrm{OH}-\mathrm{CA}$ and $7 \alpha-\mathrm{OH}-3-\mathrm{CA}$ maintained GSM activity, but were less potent than $C A$.

Our findings that CA and other steroids can modify $\mathrm{A} \beta$ production expand the growing number of studies that demonstrate how cholesterol and other steroids can modulate $A \beta$ profiles [47-54]. Of particular interest are studies showing that cholesterol binds to APP CTF $\beta$ $[22,23]$, albeit with low affinity, as this might suggest that $\mathrm{CA}$, a cholesterol metabolite, could also interact with CTF $\beta$. Our studies also show that CA behaves much like classic acidic GSMs and like all GSMs, exhibit a fairly flat SAR. Moreover, membrane lipids have been shown to alter the profile of $A \beta$ produced [55], and therefore it is theoretically possible that CA could alter $\gamma$-secretase in a similar manner. However, given the nanomolar potency of CA and the aforementioned flat SAR, we think that this mechanism of action is unlikely. As our data show that it is challenging to generate CA analogs that retain potency, we have not attempted to generate CA analogs that could be used for affinity studies to identify primary binding sites. Given the nanomolar potency of CA, we speculate that it almost certainly interacts with PSEN $/ \gamma$-secretase. However, as we have previously hypothesized, we would propose that most GSMs alter $\gamma$ secretase through a complex interaction involving both substrate and $\gamma$-secretase and possibly even other lipid membrane components $[56,57,26,58,59]$. Such a model is consistent with data showing that GSM effects are extremely sensitive to mutations within the substrate
$[59,58,60]$ and could explain why different GSM affinity probes have been shown to bind PSEN, PEN2 or C99 [56, 61-63]. It is important to consider that demonstrating binding with such a probe to a certain component does not rule out interaction with the other components, due to limitations where the reactive groups can be placed on the GSM affinity probes and the requirement for photoaffinity probes to have its photoaffinity label be in very close proximity to the bound protein.

In summary, although the endogenous metabolite CA is a potent $\gamma$-secretase modulator, i) its lack of ability to lower brain $A \beta 42$ following peripheral dosing and ii) the inability to identify additional endogenous CA analogs with increased potency, suggests that pursuing CA or $\mathrm{CA}$ analogs for further preclinical development is not likely to be fruitful. Recent data show that CA can be toxic to primary mouse motor neuron in cultures [36] and raises concerns for pursuing $\mathrm{CA}$ or $\mathrm{CA}$ derivate as possible new small molecule therapeutics for $\mathrm{AD}$. As the immediate precursor of CA, 27-OHC cholesterol, readily crosses the blood brain barrier, a pro-drug approach using a modified 27-OHC might be considered as an alternative strategy; however, emerging data that elevated 27-OHC may be a risk factor for osteoporosis and breast cancer, raises concerns about a 27-OHC cholesterol prodrug strategy to increase CA levels as well $[64,65]$.

\section{Methods}

\section{Cell culture and drug treatment}

Chinese hamster ovary $(\mathrm{CHO})$ cells stably overexpressing APP695 (CHO-2B7 cells) [66] were grown in Ham's F-12 medium (Life Technologies) supplemented with $10 \%$ fetal bovine serum and 100 units $/ \mathrm{ml}$ of penicillin and $100 \mu \mathrm{g} / \mathrm{ml}$ streptomycin. Cells were grown at $37{ }^{\circ} \mathrm{C}$ in a humidified atmosphere containing $5 \% \mathrm{CO}_{2}$ in tissue culture plates (Costar). The cells were harvested at confluence and then utilized for biochemical analyses. Compounds were dissolved in dimethyl sulfoxide (DMSO) and screened in CHO-2B7 cells. The cells were incubated for $16 \mathrm{~h}$ in the presence of the compound diluted into OptiMEM-reduced serum medium (Life Technologies, Carlsbad, CA, USA) containing $1 \%$ fetal bovine serum. Compounds used for our study were either purchased from Avanti Polar Lipids, Inc. or synthesized by SAI Life Sciences Ltd. The synthesis schemes of the newly synthesized compounds are demonstrated in Additional file 1.

\section{In vitro $\mathrm{\gamma}$-secretase assay}

Broken cell assays were performed with slight modifications from the previous studies $[67,18]$. The membrane derived from the $\mathrm{H} 4$ neuroglioma cells overexpressing APP695wt were prepared by carbonate extraction and incubated at $37{ }^{\circ} \mathrm{C}$ for $2 \mathrm{~h}$ with $\mathrm{CA}$ at various 
concentrations. $A \beta$ levels were quantified by sandwich ELISAs. For $A \beta$ and AICD spectra, the recombinant C100Flag proteins were overexpressed and purified from Escherichia coli BL21 using a HiTrap Q-column (GE Life Science, Little Chalfont, U.K.) [68, 69, 58]. The membrane containing $\gamma$-secretase was isolated from the $\mathrm{CHO}$ S-1 cell line using sodium carbonate $(100 \mathrm{mM}, \mathrm{pH} 11.0)$ [70]. For the in vitro $\gamma$-secretase assay, C100Flag recombinant protein at $25 \mu \mathrm{M}$ was incubated with the membrane $(100 \mu \mathrm{g} / \mathrm{mL})$ in the presence of CA $(20 \mu \mathrm{M})$ and DMSO in $150 \mathrm{mM}$ sodium citrate buffer ( $\mathrm{pH}$ 6.8) containing complete protease inhibitor (Roche, Indianapolis, IN) for $2 \mathrm{~h}$ at $37^{\circ} \mathrm{C}$.

\section{Mice}

All procedures were performed according to the National Institute of Health Guide for the Care and Use of Experimental Animals and were approved by the University of Florida Institutional Animal Care and Use Committee. The Cyp27a1-/- (B6.129-Cyp27a1tm1Elt/J) and Cyp7b1-/- (B6;129S-Cyp7b1tmRus/J) strains were obtained from Jackson Laboratory (Bar Harbor, ME). Cyp27a1-/- mice were bred with C57BL/6 in order to produce the heterozygous littermates of Cyp27a1, and Cyp7b1-/- mice were bred with C57BL/6 mice to produce the heterozygous Cyp7b1 littermates. The wild type, heterozygous, and knockout littermates of Cyp27a1 and Cyp7b1 mice were generated from Cyp27a1+/- X Cyp27a1+/- and Cyp7b1+/- X Cyp7b1+/-, respectively.

\section{Primary mixed neuron-glia culture}

Primary mixed neuron-glia cultures were prepared from postnatal day 0 (P0) C3HBL/6 mouse brains (Harlan Labs). Cerebral cortices were dissected from P0 mouse brains and were dissociated in $2 \mathrm{mg} / \mathrm{ml}$ papain (Worthington) and $50 \mu \mathrm{g} / \mathrm{mL}$ DNAse I (Sigma) at $37^{\circ} \mathrm{C}$ for $20 \mathrm{~min}$. They were then washed three times in sterile Hank's balanced salt solution (HBSS) to inactivate the papain and switched to $5 \%$ fetal bovine serume (HyClone) in Neurobasal-A growth media (Gibco), which includes $0.5 \mathrm{mM} \mathrm{L}$-glutamine (Gibco), $0.5 \mathrm{mM}$ GlutaMax (Life Technologies), $0.01 \%$ antibioticantimycotic (Gibco), and $0.02 \%$ SM1 supplement (Stemcell). The tissue mixture was then triturated three times using a $5 \mathrm{~mL}$ pipette followed by a Pasteur pipette, and strained through a $70 \mu \mathrm{m}$ cell strainer. The cell mixture was then centrifuged at 200xg for $3 \mathrm{~min}$, and resuspended in fresh Neurobasal-A media. They were then plated onto poly-D-lysine coated 96well plates at 100,000 cells/well. Cells were maintained in the Neurobasal-A growth media mentioned above without fetal bovine serum (FBS) at $37{ }^{\circ} \mathrm{C}$ in a humidified $5 \%$ $\mathrm{CO}_{2}$ chamber.

\section{CA IP injections}

25(R)-CA powder was initially dissolved in DMSO $(<4.5 \%$ in the final mixture) and then combined with polyethylene glycol (15)-hydroxystearate (Solutol), ethanol, and water at a ratio of (15:10:75). One molar equivalent of sodium hydroxide was added to the mixture [71, 72]. We performed CA intraperitoneal (IP) injections to wild-type mice (C57BL/6 or CF-1). The mice were injected with $25(\mathrm{R})$-CA on the right side of the abdomen. The injections have been performed with various time points (30 min, $1 \mathrm{~h}, 2 \mathrm{~h}$, and $3 \mathrm{~h}$ ) and with multiple doses $(30 \mathrm{mg}$ per $\mathrm{kg}(\mathrm{mg} / \mathrm{kg}), 60 \mathrm{mg} / \mathrm{kg}, 75 \mathrm{mg} / \mathrm{kg}$ and $100 \mathrm{mg} / \mathrm{kg}$ ). The number of each cohort is $6-8$. We used $30 \mathrm{mg} / \mathrm{kg}$ of CA for the time-course experiments, and for the dose-response experiments the end-point was set at $30 \mathrm{~min}$. The brains and serum are harvested and frozen for brain $A \beta$ extraction.

\section{Brain $A \beta$ extraction}

The mouse brains were harvested at the age of 3 months. The brains were weighed and recorded. The Diethylamine/Sodium Chloride (DEA/ $\mathrm{NaCl}$ ) extraction buffer (0.4 \% DEA) was added to each sample and homogenized using a sonicator. The samples were transferred to a poly-carbonate centrifuge tube and spun down at $50,000 \times \mathrm{xg}$ for $30 \mathrm{~min}$ at $4{ }^{\circ} \mathrm{C}$. The supernatant was loaded on the vacuum manifold with the appropriate number of HLB Oasis columns. The samples were loaded on the conditioned column, filtered, and eluted using prepared elution buffer (90\% Methanol, $2 \% \mathrm{NH} 4 \mathrm{OH}$ ). The eluates are concentrated using the Thermo-Savant SpeedVac concentrator for a minimum of $2 \mathrm{~h}$ at $55{ }^{\circ} \mathrm{C}$ with radiant heat. The concentrated samples are reconstituted in a blocking buffer $(0.67 \%$ Bovine serum albumin (BSA)) at the appropriate volume.

\section{Plasma CA analysis}

The plasma samples were extracted using published solid phase extraction method (72) and analyzed by HPLC-MS-MS. Briefly, $0.1 \mathrm{ml}$ mouse plasma samples after adding $20 \mu \mathrm{l}$ of D3-CA as internal standard were preconditioned with $1.4 \mathrm{ml}$ of ethanol (99.9\%), and $0.5 \mathrm{ml}$ of water, centrifuged at $4{ }^{\circ} \mathrm{C}, 4000 \mathrm{rpm}$ for $10 \mathrm{~min}$. This solution was then loaded onto a Sep-Pak tC18 (SPE1) solid phase extraction cartridge which were preconditioned with $70 \%$ ethanol. The sample was washed with one column volume of $70 \%$ ethanol then eluted from the column by $2+1 \mathrm{ml}$ of $99.9 \%$ ethanol; it was dried in centrifuge evaporator. The residue was reconstituted in $100 \mu \mathrm{l}$ of isopropanol. It was oxidized by adding $1 \mathrm{ml}$ of $50 \mathrm{mM}$ phosphate buffer $(\mathrm{pH}=7)$ containing $3 \mu \mathrm{l}$ of cholesterol oxidase and incubated at $37{ }^{\circ} \mathrm{C}$ for $1 \mathrm{~h}$, quenched with $1.9 \mathrm{ml}$ of methanol. The mixture was further processed by adding $150 \mu \mathrm{l}$ glacial 
acetic acid and 1 smidgen (about $80 \mathrm{mg}$ ) GP reagent \{1-(carboxymethyl) pyridinium chloride hydrazide\} and incubated at room temperature overnight in the dark. On the next day, a second solid phase extraction [73] was employed to separate the derivatized CA from the excess derivatization reagent using the following: Sep-pak C18 (SPE 2, different from SPE1) cartridge with 1 column volume of $99.9 \%$ methanol and 1 column volume of $10 \%$ methanol, after application of the sample wash with $10 \%$ methanol, then elute with $2 \% 1 \mathrm{ml}$ of $100 \%$ methanol. Mix $200 \mu \mathrm{l}$ of the elution solution with $50 \mu \mathrm{l}$ of water to obtain $250 \mu \mathrm{l}$ of $80 / 20$ (methanol/water, $\mathrm{v} / \mathrm{v})$ samples. $20 \mu \mathrm{l}$ was injected onto HPLC-MS-MS for analysis.

HPLC-MS-MS conditions: HPLC contains a Perkin Elmer series 200 autosampler and a Perkin Elmer series 200 pump, MS-MS was Waters Quattro LC-Z, ES positive mode, Cone voltage 45 volts, collision energy 30volts, Desolvation temperature $350{ }^{\circ} \mathrm{C}$. Source block temperature $120{ }^{\circ} \mathrm{C}$. MS/MS transitions: CA 549.0/ 470.0; D3-CA 552.0/473.0. HPLC mobile phase was 80/ 20 Methanol/water(v/v) containing 0.1 \%Formic Acid, HPLC column was ThermoFisher Hypersil Gold, $50 * 2.1 \mathrm{~mm}, 1.9 \mu$, flow rate $0.2 \mathrm{ml} / \mathrm{min}$. Injection volume $20 \mu \mathrm{l}$, run time $4 \mathrm{~min}$, CA retention time $1.4 \mathrm{~min}$.

\section{Antibodies and ELISAs}

Monoclonal antibodies to $A \beta$ were generated by the Mayo Clinic Immunology Core facilities (Jacksonville, FL, USA). Ab5 recognizes an epitope in the amino terminus of $A \beta$ (A $\beta 1-16)$, recognizes both monomeric and aggregated $A \beta$, and is human specific. Ab13.1.1. was raised against $A \beta 35-40$ and is specific for $A \beta x-40$, and exhibits minimal cross-reactivity with other $A \beta$ peptides. $A b$ 2.1.3 was raised against $A \beta 35-42$ and is specific for $\mathrm{A} \beta \mathrm{x}-42$. The $\mathrm{A} \beta 38$ antibody (Ab38), supplied by $\mathrm{P}$. Mehta (Institute of Basic Research, Staten Island, NY, USA), specifically recognizes $A \beta x-38$ and shows no cross-reactivity with other $A \beta$ peptides [74]. For cellbased screens, $A \beta$ was captured from conditioned medium with either Ab5, Ab38, Ab13.1.1, or Ab2.1.3 (coated at 10-50 $\mu \mathrm{g} / \mathrm{ml}$ in EC buffer: $5 \mathrm{mM} \mathrm{NaH} 2 \mathrm{PO} 4-$ $\mathrm{H} 2 \mathrm{O}, 20 \mathrm{mM}$ Na2HPO4, $400 \mathrm{mM} \mathrm{NaCl}, 2.5 \mathrm{mM}$ EDTA-full name, $151.5 \mu \mathrm{M}$ BSA, $813 \mu \mathrm{M}$ CHAPS, and $7.7 \mathrm{mM} \mathrm{NaN3}$ ) on Immulon 4HBX Flat-Bottom Microfilter 96-well plates (Thermo Scientific, Waltham, MA, USA). Total A $\beta$ level was determined by capture with $\mathrm{Ab} 5$ and detected with horseradish peroxidase (HRP)conjugated 4G8 (a monoclonal antibody against $A \beta 17$ 24; Covance, Waltham, MA, USA) with the other $A \beta$ peptides detected with HRP-conjugated Ab5. For the cell-free assay and measuring mouse endogenous $A \beta$, HRP-conjugated 4G8 was used as the secondary detection antibody. A $\beta$ standards (Bachem, King of Prussia,
PA, USA) were prepared by dissolving in hexafluoroisopropanol (HFIP) at $1 \mathrm{mg} / \mathrm{ml}$ with sonication, dried under nitrogen, resuspended at $2 \mathrm{mg} / \mathrm{ml}$ HFIP, sonicated again and dried under nitrogen. The resulting $A \beta$ was resuspended in $0.01 \%$ ammonium hydroxide, portioned into aliquots in EC buffer, and frozen at $-80^{\circ} \mathrm{C}$. Following these steps, the $\mathrm{A} \beta$ is monomeric, as determined by size-exclusion chromatography.

\section{Immunoprecipitation-Mass spectrometry}

Conditioned media from the $\mathrm{CHO}-2 \mathrm{~B} 7$ cells and the samples prepared from in vitro $\gamma$-secretase studies were used to analyze $A \beta$ and AICD profiles using matrixassisted laser desorption/ionization time of flight (MALDI-TOF) mass spectrometry analysis. The secreted $A \beta$ peptides were analyzed as previously described with the following modifications $[2,75,76]$. Briefly, the $A \beta$ peptides were immunoprecipitated using Ab5 recognizing the A $\beta 1-16$ epitope [77] and sheep anti-mouse IgG magnetic Dynabeads (Life Technologies, catalog no. 11201D) and the AICD fragments were captured using anti-Flag M2 magnetic beads (Sigma). The samples were washed and eluted with $10 \mu \mathrm{M}$ solution of $0.1 \%$ trifluoroacetic acid (TFA) in water. Eluted samples were mixed 2:1 with saturated $\alpha$-cyano-4-hydroxycinnamic acid (CHCA) matrix (Sigma) in acetonitrile: methanol $(60: 40 \%)$ and loaded onto a CHCA pretreated MSP 96 target platepolished steel (Bruker, Billerica, MA, USA - Part No.224989). Samples were analyzed using a Bruker Microflex LRF-MALDI-TOF mass spectrometer.

\section{Statistics}

In vitro data were expressed and graphed as the mean \pm SEM using GraphPad Prism 5 software. Analysis was by one-way analysis of variance (ANOVA) followed by Dunnett's multiple comparisons, and was by two-way analysis of variance (ANOVA) followed by bonferroni post-hoc testing for group differences. The level of significance was set at $p<0.05$ in all tests.

\section{Additional file}

Additional file 1: Schematics of syntheses of (25R)-cholestenoic

acid and its analogs.

\section{Abbreviations \\ AB: Amyloid- $\beta$; AD: Alzheimer's disease; APP: Amyloid precursor protein: AICD: APP intracellular domain; CTF: APP carboxyl terminal fragment; CA: Cholestenoic acid; Cyp: Cytochrome P450; CHO: Chinese hamster ovary; CTX: Cerebrotendinous xanthomatosis; GSM: $\gamma$-secretase modulator; NSAID: Non-steroidal anti-inflammatory drug; SPG5: Spastic paraplegia 5; SAR: Structure-activity relationship.}

\section{Competing interests}

The authors declare that they have no competing interests. 


\section{Authors' contributions}

JIJ participated in study design, performed in vitro and cell-based immunoassays, analyzed data, and drafted manuscript. APR and LAS participated in animal study design and performed ELISA. TBL and YR performed in vitro and cell-based assays. HJP and CCD performed primary neuronal culture and ELISA. GH and YT participated in pharmacokinetics study and performed LC-MS/MS. RA and SB synthesized CA analogs, which were designed by GS. EHK was involved in experimental interpretation and manuscript editing. GS, KMF, and TEG participated in study design and coordination and in manuscript preparation and editing. All authors read and approved the final manuscript.

\section{Acknowledgements}

We thank Patricia Joy for critical reading of this manuscript. This study was funded in NIH NIA P01 AG020206 grant (EHK and TEG).

\section{Author details}

${ }^{1}$ Center for Translational Research in Neurodegenerative Disease, University of Florida, Gainesville, FL 32610, USA. ²Department of Neuroscience, University of Florida, Gainesville, FL 32610, USA. ${ }^{3}$ McKnight Brain Institute, College of Medicine, University of Florida, Gainesville, FL 32610, USA. ${ }^{4}$ College of Pharmacy, University of Florida, Gainesville, FL 32610, USA. ${ }^{5}$ SAI Life Sciences Ltd., Turkapally AP500078, India. 'Department of Neuroscience, University of California, La Jolla, San Diego, CA 92093, USA. ${ }^{7}$ Pharmore, Inc., Gainesville, FL 32653, USA. ${ }^{8}$ Departments of Medicine and Physiology, Yong Loo Lin School of Medicine, National University of Singapore, Singapore 119077, Singapore.

\section{Received: 6 April 2015 Accepted: 29 May 2015}

Published online: 14 July 2015

\section{References}

1. Golde TE, Eckman CB, Younkin SG. Biochemical detection of A isoforms: implications for pathogenesis, diagnosis, and treatment of Alzheimer's disease. Biochim Biophys Acta. 2000;1502(1):172-87. doi:10.1016/s09254439(00)00043-0

2. Wang R, Sweeney D, Gandy SE, Sisodia SS. The Profile of Soluble Amyloid $\beta$ Protein in Cultured Cell Media: detection and quantification of amyloid $\beta$ protein and variants by immunoprecipitation-mass spectrometry. J Biol Chem. 1996;271(50):31894-902.

3. Suzuki N, Cheung TT, Cai XD, Odaka A, Otvos L, Eckman C, et al. An increased percentage of long amyloid beta protein secreted by familial amyloid beta protein precursor (beta APP717) mutants. Science (New York, NY). 1994;264(5163):1336-40.

4. Younkin S. The role of A beta 42 in Alzheimer's disease. J Physiol Paris. 1998;92:289-92.

5. Kim J, Onstead L, Randle S, Price R, Smithson L, Zwizinski C, et al. A 440 Inhibits Amyloid Deposition In Vivo. J Neurosci. 2007;27(3):627-33. doi:10.1523/jneurosci.4849-06.2007.

6. McGowan E, Pickford F, Kim J, Onstead L, Eriksen J, Yu C, et al. Abeta42 is essential for parenchymal and vascular amyloid deposition in mice. Neuron. 2005:47:191-9.

7. Borchelt DR, Thinakaran G, Eckman CB, Lee MK, Davenport F, Ratovitsky T, et al. Familial Alzheimer's Disease-Linked Presenilin 1 Variants Elevate Aß1-42/1-40 Ratio In Vitro and In Vivo. Neuron. 1996;17(5):1005-13. doi:http://dx.doi.org/10.1016/S0896-6273(00)80230-5.

8. Duff K, Eckman C, Zehr C, Yu X, Prada C-M, Perez-tur J, et al. Increased amyloid-[beta]42(43) in brains of mice expressing mutant presenilin 1. Nature. 1996;383(6602):710-3

9. Scheuner D. Secreted amyloid $\beta$-protein similar to that in the senile plaques of Alzheimer's disease is increased in vivo by the presenilin 1 and 2 and APP mutations linked to familial Alzheimer's disease. Nat Med. 1996;2:864-70. doi:10.1038/nm0896-864.

10. Murayama O, Tomita T, Nihonmatsu N, Murayama M, Sun X, Honda T, et al Enhancement of amyloid $\beta 42$ secretion by 28 different presenilin 1 mutations of familial Alzheimer's disease. Neurosci Lett. 1999;265(1):61-3. doi:http://dx.doi.org/10.1016/S0304-3940(99)00187-1.

11. Caughey B, Lansbury PT. Protofibrils, pores, fibrils, and neurodegeneration: Separating the Responsible Protein Aggregates from The Innocent Bystanders*. Annual Review of Neuroscience. 2003;26(1):267-98. doi:10.1146/annurev.neuro.26.010302.081142.
12. Wang $\mathrm{R}$, Wang $\mathrm{B}, \mathrm{He} \mathrm{W}$, Zheng $\mathrm{H}$. Wild-type Presenilin 1 Protects against Alzheimer Disease Mutation-induced Amyloid Pathology. Journal of Biological Chemistry. 2006;281(22):15330-6. doi:10.1074/jbc.M512574200.

13. Seubert $P$, Vigo-Pelfrey $C$, Esch $F$, Lee $M$, Dovey $H$, Davis $D$, et al. Isolation and quantification of soluble Alzheimer's b-peptide from biological fluids. Nature. 1992;359(6393):325-7.

14. Iwatsubo T, Odaka A, Suzuki N, Mizusawa H, Nukina N, Ihara Y. Visualization of $A \beta 42(43)$ and $A B 40$ in senile plaques with end-specific $A B$ monoclonals: Evidence that an initially deposited species is $A \beta 42(43)$. Neuron. 1994;13(1):45-53. doi:10.1016/0896-6273(94)90458-8.

15. Gravina SA, Ho L, Eckman CB, Long KE, Otvos L, Younkin LH, et al. Amyloid $\beta$ Protein (AB) in Alzheimeri's Disease Brain. J Biol Chem. 1995;270(13):7013-6. doi:10.1074/jbc.270.13.7013.

16. Moore B, Chakrabarty $P$, Levites $Y$, Kukar T, Baine A-M, Moroni T, et al. Overlapping profiles of Abeta peptides in the Alzheimer's disease and pathological aging brains. Alzheimer's Research \& Therapy. 2012;4(3):18.

17. McGowan E, Pickford F, Kim J, Onstead L, Eriksen J, Yu C, et al. Aß42 Is Essential for Parenchymal and Vascular Amyloid Deposition in Mice. Neuron. 2005:47(2):191-9. doi:10.1016/j.neuron.2005.06.030.

18. Wahrle S, Das P, Nyborg AC, McLendon C, Shoji M, Kawarabayashi T, et al. Cholesterol-Dependent $\gamma$-Secretase Activity in Buoyant Cholesterol-Rich Membrane Microdomains. Neurobiol Dis. 2002;9(1):11-23. doi:10.1006/ nbdi.2001.0470.

19. Ehehalt R, Keller P, Haass C, Thiele C, Simons K. Amyloidogenic processing of the Alzheimer $\beta$-amyloid precursor protein depends on lipid rafts. The Journal of Cell Biology. 2003;160(1):113-23. doi:10.1083/jcb.200207113.

20. Song C, Liao S. Cholestenoic Acid Is a Naturally Occurring Ligand for Liver $X$ Receptor a. Endocrinology. 2000;141(11):4180-4. doi:10.1210/en.141.11.4180.

21. Golde TE, Eckman CB. Cholesterol modulation as an emerging strategy for the treatment of Alzheimer's disease. Drug Discovery Today. 2001;6(20):1049-55. doi:10.1016/s1359-6446(01)01965-1.

22. Beel AJ, Sakakura M, Barrett PJ, Sanders CR. Direct binding of cholesterol to the amyloid precursor protein: An important interaction in lipid-Alzheimer's disease relationships? Biochimica et Biophysica Acta (BBA) - Molecular and Cell Biology of Lipids. 2010;1801(8):975-82. doi:10.1016/j.bbalip.2010.03.008.

23. Barrett PJ, Song Y, Van Horn WD, Hustedt EJ, Schafer JM, Hadziselimovic A, et al. The Amyloid Precursor Protein Has a Flexible Transmembrane Domain and Binds Cholesterol. Science. 2012;336(6085):1168-71. doi:10.1126/ science.1219988

24. Grimm MOW, Grimm HS, Tomic I, Beyreuther K, Hartmann T, Bergmann C. Independent Inhibition of Alzheimer Disease $\beta$ - and $\gamma$-Secretase Cleavage by Lowered Cholesterol Levels. Journal of Biological Chemistry. 2008;283(17):11302-11. doi:10.1074/jbc.M801520200.

25. Levin-Allerhand JA, Lominska CE, Wang J, Smith JD. 17a-estradiol and $17 \beta$-estradiol treatments are effective in lowering cerebral amyloid- $\beta$ levels in AßPPSWE transgenic mice. Journal of Alzheimer's Disease. 2002;4(6):449-57.

26. Jung Jl, Ladd TB, Kukar T, Price AR, Moore BD, Koo EH, et al. Steroids as $\gamma$-secretase modulators. FASEB J. 2013;27:3775-85. doi:10.1096/fj.12-225649.

27. Kukar T, Golde TE. Possible mechanisms of action of NSAIDs and related compounds that modulate g-secretase cleavage. Curr Top Med Chem. 2008;8(1):47-53.

28. Weggen S, Eriksen JL, Das P, Sagi SA, Wang R, Pietrzik CU, et al. A subset of NSAIDs lower amyloidogenic A[beta]42 independently of cyclooxygenase activity. Nature. 2001;414(6860):212-6. http://www.nature.com/nature/ journal/v414/n6860/full/414212a0.html.

29. Eriksen JL, Sagi SA, Smith TE, Weggen S, Das P, McLendon DC, et al. NSAIDs and enantiomers of flurbiprofen target $\gamma$-secretase and lower $A \beta 42$ in vivo. The Journal of Clinical Investigation. 2003;112(3):440-9. doi:10.1172/jci18162.

30. Beel AJ, Sanders CR. Substrate specificity of $y$-secretase and other intramembrane proteases. Cell Mol Life Sci. 2008;65(9):1311-34. doi:10.1007/s00018-008-7462-2.

31. Meaney S, Heverin M, Panzenboeck U, Ekström L, Axelsson M, Andersson U, et al. Novel route for elimination of brain oxysterols across the blood-brain barrier: conversion into 7a-hydroxy-3-oxo-4-cholestenoic acid. Journal of Lipid Research. 2007:48(4):944-51. doi:10.1194/jlr.M600529-JLR200.

32. Sundaram SS, Bove KE, Lovell MA, Sokol RJ. Mechanisms of Disease: inborn errors of bile acid synthesis. Nat Clin Pract Gastroenterol Hepatol. 2008;5(8):456-68.

33. Rosen H, Reshef A, Maeda N, Lippoldt A, Shpizen S, Triger L, et al. Markedly Reduced Bile Acid Synthesis but Maintained Levels of Cholesterol and Vitamin 
D Metabolites in Mice with Disrupted Sterol 27-Hydroxylase Gene. Journal of Biological Chemistry. 1998;273(24):14805-12. doi:10.1074/jbc.273.24.14805.

34. Honda A, Salen G, Matsuzaki Y, Batta AK, Xu G, Leitersdorf E, et al. Differences in hepatic levels of intermediates in bile acid biosynthesis between Cyp27-/- mice and CTX. Journal of Lipid Research. 2001;42(2):291-300.

35. Li-Hawkins J, Lund EG, Turley SD, Russell DW. Disruption of the Oxysterol 7a-Hydroxylase Gene in Mice. Journal of Biological Chemistry. 2000;275(22):16536-42. doi:10.1074/jbc.M001811200.

36. Theofilopoulos S, Griffiths WJ, Crick PJ, Yang S, Meljon A, Ogundare M, et al. Cholestenoic acids regulate motor neuron survival via liver $X$ receptors. The Journal of Clinical Investigation. 2014;124(11):4829-42. doi:10.1172/jci68506.

37. Page RM, Baumann K, Tomioka M, Pérez-Revuelta BI, Fukumori A, Jacobsen $H$, et al. Generation of $A \beta 38$ and $A \beta 42$ Is Independently and Differentially Affected by Familial Alzheimer Disease-associated Presenilin Mutations and -Secretase Modulation. J Biol Chem. 2008;283(2):677-83. doi:10.1074/jbc.M708754200.

38. Babiker $A$, Andersson $\mathrm{O}$, Lindblom $\mathrm{D}$, van der Linden J, Wiklund $\mathrm{B}$, Lütjohann $D$, et al. Elimination of cholesterol as cholestenoic acid in human lung by sterol 27-hydroxylase: evidence that most of this steroid in the circulation is of pulmonary origin. Journal of Lipid Research. 1999;40(8):1417-25.

39. Setchell KD, Schwarz M, O'Connell NC, Lund EG, Davis DL, Lathe $R$, et al. Identification of a new inborn error in bile acid synthesis: mutation of the oxysterol 7alpha-hydroxylase gene causes severe neonatal liver disease. The Journal of Clinical Investigation. 1998;102(9):1690-703.

40. Ogundare M, Theofilopoulos S, Lockhart A, Hall LJ, Arenas E, Sjövall J, et al Cerebrospinal Fluid Steroidomics: Are Bioactive Bile Acids Present in Brain? Journal of Biological Chemistry. 2010;285(7):4666-79. doi:10.1074/ jbc.M109.086678.

41. Khan SN, Kim BJ, Kim H-S. Synthesis and antimicrobial activity of 7-fluoro-3aminosteroids. Bioorganic \& Medicinal Chemistry Letters. 2007;17(18):5139-42. doi:http://dx.doi.org/10.1016/j.bmcl.2007.07.001.

42. Marwah P, Thoden JB, Powell DR, Lardy HA. Steroidal allylic fluorination using diethylaminosulfur trifluoride: A convenient method for the synthesis

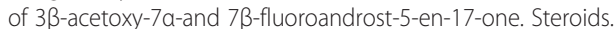
1996;61(8):453-60. doi:http://dx.doi.org/10.1016/0039-128X(96)00092-X.

43. Imbimbo BP, Del Giudice E, Cenacchi V, Volta R, Villetti G, Facchinetti F, et al. In vitro and in vivo profiling of CHF5022 and CHF5074: Two $\beta$-amyloid1-42 lowering agents. Pharmacological Research. 2007;55(4):318-28. doi:http://dx.doi.org/10.1016/j.phrs.2006.12.010.

44. Peretto I, Radaelli S, Parini C, Zandi M, Raveglia LF, Dondio G, et al. Synthesis and Biological Activity of Flurbiprofen Analogues as Selective Inhibitors of B-Amyloid1-42 Secretion. Journal of Medicinal Chemistry. 2005;48(18):5705-20. doi:10.1021/jm0502541.

45. Björkhem I, Leitersdorf E. Sterol 27-hydroxylase Deficiency: A Rare Cause of Xanthomas in Normocholesterolemic Humans. Trends in Endocrinology \&amp; Metabolism. 2000;11(5):180-3. doi:10.1016/s1043-2760(00)00255-1.

46. Lorbek G, Lewinska M, Rozman D. Cytochromes P450 in Synthesis of Cholesterol and Bile Acids: From Mouse Models to Human Diseases. FEBS Journal. 2011. doi:10.1111/j.1742-4658.2011.08432.x

47. Fuller N, Hubbs J, Austin W, Creaser S, McKee T, Loureiro R, et al. The initial optimization of a new series of gamma-secretase modulators derived from a triterpene glycoside. ACS Med Chem Lett. 2012;3:908-13.

48. Burg VK, Grimm HS, Rothhaar TL, Grösgen S, Hundsdörfer B, Haupenthal VJ, et al. Plant Sterols the Better Cholesterol in Alzheimer's Disease? A Mechanistical Study. The Journal of Neuroscience. 2013;33(41):16072-87. doi:10.1523/jneurosci.1506-13.2013.

49. Urano $Y$, Ochiai $S$, Noguchi N. Suppression of amyloid- $\beta$ production by $24 S-$ hydroxycholesterol via inhibition of intracellular amyloid precursor protein trafficking. The FASEB Journal. 2013;27(10):4305-15. doi:10.1096/fj.13-231456.

50. Irwin RW, Brinton RD. Allopregnanolone as regenerative therapeutic for Alzheimer's disease: Translational development and clinical promise Progress in Neurobiology. 2014;113(0):40-55. doi:http://dx.doi.org/10.1016/ j.pneurobio.2013.08.004.

51. Amtul Z, Wang L, Westaway D, Rozmahel RF. Neuroprotective mechanism conferred by 17beta-estradiol on the biochemical basis of Alzheimer's disease. Neuroscience. 2010;169(2):781-6. doi:10.1016/ j.neuroscience.2010.05.031.

52. Sun J-H, Yu J-T, Tan L. The Role of Cholesterol Metabolism in Alzheimer's Disease. Mol Neurobiol. 2014:1-19. doi:10.1007/s12035-014-8749-y
53. Popp J, Lewczuk P, Kölsch H, Meichsner S, Maier W, Kornhuber J, et al. Cholesterol metabolism is associated with soluble amyloid precursor protein production in Alzheimer's disease. Journal of Neurochemistry. 2012;123(2):310-6. doi:10.1111/j.1471-4159.2012.07893.x.

54. Hubbs J, Fuller N, Austin W, Shen R, Creaser S, McKee T, et al. Optimization of a natural product-based class of gamma-secretase modulators. J Med Chem. 2012:55:9270-82.

55. Holmes O, Paturi S, Ye W, Wolfe MS, Selkoe DJ. Effects of Membrane Lipids on the Activity and Processivity of Purified $\gamma$-Secretase. Biochemistry. 2012;51(17):3565-75. doi:10.1021/bi300303g.

56. Kukar TL, Ladd TB, Bann MA, Fraering PC, Narlawar R, Maharvi GM, et al. Substratetargeting g-secretase modulators. Nature. 2008;453(7197):925-9. doi:http:// www.nature.com/nature/journal/v453/n7197/suppinfo/nature07055_S1.html.

57. Kukar TL, Ladd TB, Robertson P, Pintchovski SA, Moore B, Bann MA, et al. Lysine 624 of the Amyloid Precursor Protein (APP) Is a Critical Determinant of Amyloid $\beta$ Peptide Length. J Biol Chem. 2011;286(46):39804-12. doi:10.1074/jbc.M111.274696

58. Jung Jl, Ran Y, Cruz PE, Rosario AM, Ladd TB, Kukar TL, et al. Complex Relationships between Substrate Sequence and Sensitivity to Alterations in $\gamma$-Secretase Processivity Induced by $\gamma$-Secretase Modulators. Biochemistry. 2014;53(12):1947-57. doi:10.1021/bi401521t.

59. Jung Jl, Premraj S, Cruz PE, Ladd TB, Kwak Y, Koo EH, et al. Independent Relationship between Amyloid Precursor Protein (APP) Dimerization and Y-Secretase Processivity. PLoS ONE. 2014;9(10):e111553. doi:10.1371/ journal.pone.0111553.

60. Sagi SA, Lessard CB, Winden KD, Maruyama H, Koo JC, Weggen S, et al. Substrate Sequence Influences $\gamma$-Secretase Modulator Activity, Role of the Transmembrane Domain of the Amyloid Precursor Protein. J Biol Chem. 2011;286(46):39794-803. doi:10.1074/jbc.M111.277228.

61. Ohki Y, Higo T, Uemura K, Shimada N, Osawa S, Berezovska O, et al. Phenylpiperidine-type [gamma]-secretase modulators target the transmembrane domain 1 of presenilin 1. EMBO J. 2011;30(23):4815-24. http://emboj.embopress.org/content/30/23/4815.long.

62. Jumpertz T, Rennhack A, Ness J, Baches S, Pietrzik CU, Bulic B, et a Presenilin is the molecular target of acidic gamma-secretase modulators in living cells. PLOS ONE. 2012;7:e30484.

63. Ebke A, Luebbers T, Fukumori A, Shirotani K, Haass C, Baumann K, et al. Novel $\gamma$-Secretase Enzyme Modulators Directly Target Presenilin Protein. J Biol Chem. 2011;286(43):37181-6. doi:10.1074/jbc.C111.276972.

64. Nelson ER, DuSell CD, Wang X, Howe MK, Evans G, Michalek RD, et al. The Oxysterol, 27-Hydroxycholesterol, Links Cholesterol Metabolism to Bone Homeostasis Through Its Actions on the Estrogen and Liver X Receptors. Endocrinology. 2011;152(12):4691-705. doi:10.1210/en.2011-1298.

65. Nelson ER, Chang C-y, McDonnell DP. Cholesterol and breast cancer pathophysiology. Trends in Endocrinology \& Metabolism. 2014;25(12):649-55. doi:http://dx.doi.org/10.1016/j.tem.2014.10.001

66. Murphy MP, Uljon SN, Fraser PE, Fauq A, Lookingbill HA, Findlay KA, et al. Presenilin 1 regulates pharmacologically distinct $g$-secretase activities. Implications for the role of presenilin in g-secretase cleavage. J Biol Chem. 2000;275:26277-84.

67. McLendon C, Xin T, Ziani-Cherif C, Murphy MP, Findlay KA, Lewis PA, et al. Cell-free assays for g-secretase activity. The FASEB Journal. 2000. doi:10.1096/fj.00-0286fje.

68. Kimberly WT, Esler WP, Ye W, Ostaszewski BL, Gao J, Diehl T, et al. Notch and the Amyloid Precursor Protein Are Cleaved by Similar $\gamma$-Secretase(s). Biochemistry. 2003;42(1):137-44. doi:10.1021/bi026888g.

69. Esler WP, Kimberly WT, Ostaszewski BL, Ye W, Diehl TS, Selkoe DJ, et al. Activity-dependent isolation of the presenilin- $\gamma$-secretase complex reveals nicastrin and a $y$ substrate. Proc Natl Acad Sci USA. 2002;99(5):2720-5. doi:10.1073/pnas.052436599.

70. Fraering PC, Ye W, LaVoie MJ, Ostaszewski BL, Selkoe DJ, Wolfe MS. YSecretase Substrate Selectivity Can Be Modulated Directly via Interaction with a Nucleotide-binding Site. J Biol Chem. 2005;280(51):41987-96. doi:10.1074/jbc.M501368200.

71. Price AR, Xu G, Siemienski ZB, Smithson LA, Borchelt DR, Golde TE, et al. Comment on "ApoE-Directed Therapeutics Rapidly Clear $\beta$-Amyloid and Reverse Deficits in AD Mouse Models". Science. 2013;340(6135):924. doi:10.1126/science.1234089.

72. Shen Q. Improvement of colchicine oral bioavailability by incorporating eugenol in the nanoemulsion as an oil excipient and enhancer. Int J Nanomedicine. 2011;6:1237-43. 
73. Karu K, Hornshaw M, Woffendin G, Bodin K, Hamberg M, Alvelius G, et al. Liquid chromatography-mass spectrometry utilizing multi-stage fragmentation for the identification of oxysterols. Journal of Lipid Research. 2007:48(4):976-87. doi:10.1194/jlr.M600497-JLR200.

74. Jung Jl, Ladd TB, Kukar T, Price AR, Moore BD, Koo EH, et al. Steroids as $\gamma$-secretase modulators. The FASEB Journal. 2013;27(9):3775-85. doi:10.1096/fj.12-225649.

75. Kukar T, Murphy MP, Eriksen JL, Sagi SA, Weggen S, Smith TE, et al. Diverse compounds mimic Alzheimer disease-causing mutations by augmenting Ab42 production. Nat Med. 2005;11(5):545-50. http://www.nature.com/nm/ journal/v11/n5/full/nm1235.html.

76. Murphy MP, Uljon SN, Fraser PE, Fauq A, Lookingbill HA, Findlay KA, et al. Presenilin 1 regulates pharmacologically distinct $\psi$-secretase activities: implications for the role of presenilin in $\gamma$-secretase cleavage. J Biol Chem. 2000;275(34):26277-84. doi:10.1074/jbc.M002812200.

77. Levites Y, Das P, Price RW, Rochette MJ, Kostura LA, McGowan EM, et al. Anti-A 42 - and anti-A $340-$ specific mAbs attenuate amyloid deposition in an Alzheimer disease mouse model. J Clin Invest. 2006;116(1):193-201. doi:10.1172/jci25410.

\section{Submit your next manuscript to BioMed Central and take full advantage of:}

- Convenient online submission

- Thorough peer review

- No space constraints or color figure charges

- Immediate publication on acceptance

- Inclusion in PubMed, CAS, Scopus and Google Scholar

- Research which is freely available for redistribution 